\title{
ALGUMAS FACETAS DA PESQUISA NA ESCOLA
}

\section{SOME FACETS OF RESEARCH IN SCHOOL}

Elizangela da Rocha Fernandes ${ }^{1}$

Resumo: O objetivo deste artigo é discutir sobre a Alfabetizaçăo Cientifica ( $A C$ ) e o Letramento Científico (LC) na educaçâo básica. Sâo apresentadas algumas análises de práticas de pesquisa e produçâo de gênero discursivo ocorridas na iniciaçăo científica de educandos da rede municipal de ensino de Palmas - Tocantins. Evidenciou-se uma educaçâo científica incipiente, porém de grande magnitude, posto que a preocupaçâo em iniciar os discentes ainda no ensino fundamental, na esfera científica, já é um grande avanço na educaçấo. A presença notável da escolarizaçăo das atividades de pesquisa propiciou também questionamento sobre o empreendimento da educaçăo científica nas instituiçôes de ensino e apontou lacunas que demonstraram a necessidade de possíveis melhorias para que a AC e o LC se efetivem nas instituiçōes educacionais com mais maestria.

Palavras-chave: Alfabetizaçăo científica. Gêneros. Iniciaçăo científica. Letramento científico.

Abstract: The aim of this paper is to discuss scientific alphabetization (SA) and scientific literacy (SL) in basic education. We presented some analyses of research practices and discursive genre production developed in the scientific initiation of students in a municipal school system in the city of Palmas - Tocantins States. An incipient, but of great magnitude, scientific education was evidenced, since the concern to initiate students still in elementary education, in the scientific sphere, is already a great advance in education. The notable presence of the schooling of research activities also led to questions about the development of scientific education in educational institutions and pointed to gaps that demonstrated the need for possible improvements so that SA and SL become more effective in educational institutions.

Keywords: Scientific literacy. Genres. Scientific initiation. Scientific literacy.

\section{INTRODUÇÃO}

Neste artigo compartilhamos alguns resultados de uma pesquisa de mestrado acadêmico, que objetivou entender como os gêneros discursivos organizaram as atividades de iniciaçáo científica e contribuíram para o fortalecimento do letramento científico (LC) de alunos do ensino fundamental da rede municipal de ensino de Palmas, Estado

1 Mestra em Letras: Ensino de Língua e Literatura pela Universidade Federal do Tocantins (UFT). E-mail: elizan_gbi@hotmail.com 
do Tocantins. Os alunos participaram de feiras de ciências escolares e extraescolares, a exemplo da Feira de Ciências, Inovaçăo e Tecnologia de Palmas (FECIT) e da Feira Brasileira de Ciência e Engenharia (FEBRACE) ${ }^{2}$.

A FECIT é realizada anualmente no mês de outubro na capital tocantinense. Foi instituída em 20 de março de 2014 pela PORTARIA/GAB/SEMED/N0361, com o objetivo de mobilizar a populaçấo, principalmente, crianças e jovens a respeito da Ciência, Inovaçăo e Tecnologia, com o fito de identificar talentos, valorizar a criatividade dos discentes e propiciar discussóes sobre as estratégias e mudanças necessárias para a divulgaçăo da ciência (PALMAS, 2014).

A FEBRACE é realizada desde o ano de 2003 com os seguintes objetivos: (i) estimular novas vocaçóes em ciências e engenharia com o desenvolvimento de projetos criativos e inovadores; (ii) aproximar as escolas públicas e privadas das universidades; e (iii) criar uma oportunidade para jovens pré-universitários brasileiros entrarem em contato com diferentes culturas e reconhecidos cientistas (FEBRACE, 2016).

Esta pesquisa foi pautada pela abordagem investigativa qualitativa, configurando-se como um estudo de caso com vertente etnográfica. Está inserida no campo de estudos interdisciplinares da Linguística Aplicada (LA) e se pauta nas teorias do letramento - configurada como área de atuaçăo direta do linguista aplicado. A preocupaçáo cada vez maior da LA centra-se em investigar o uso da linguagem em contextos institucionais de açăo focalizando mais a interaçăo "para se ter acesso a como as pessoas agem no mundo através do discurso" (MOITA LOPES, 1998, p. 123).

A etnografia "é a arte de descrever um grupo humano - suas intuiçôes, seus comportamentos interpessoais, suas produçōes materiais e suas crenças" (ANGROSINO, 2009, p. 30). Em se tratando de pesquisa na área educacional, o foco da pesquisa etnográfica deve estar relacionado ao processo educacional (OLIVEIRA, 2002), isto é, como esse processo acontece e como os envolvidos reagem, interagem, aprendem e apreendem no fazer educativo.

Esta pesquisa se pautou em observar a realidade em estudo com ênfase nas interaçôes comunicativas, em algumas formas de enunciaçăo, principalmente no que concerne aos gêneros escritos durante as atividades de iniciaçăo científica. Neste artigo, săo analisados três projetos de pesquisa inscritos na FECIT, elaborados por discentes de escolas municipais da capital tocantinense.

Este texto está organizado em quatro seçōes principais, além desta Introduçâo, das Consideraçôes finais e das Referências. Em Letramento científico - busca de uma inclusâo, é apresentada uma breve introduçăo sobre o significado do termo e o interesse pela temática no Brasil. Em Alfabetizaçâo científica e letramento científico - a guisa de uma compreensâo, há algumas explanaçôes sobre as temáticas mediante discussăo de algumas perspectivas teóricas. Em Projetos, nâo! Pesquisas, sim ou nâo?, há analises de dois supostos projetos de pesquisa inscritos na feira científica local. Por

2 Dissertaçāo intitulada "Letramento Científico no Ensino Básico Público no Município de Palmas - Tocantins", apresentada, em 2016, ao Programa de Pós-graduaçăo em Letras: Ensino de Língua e Literatura, na Universidade Federal do Tocantins (UFT), sob a orientaçáo do Prof. Dr. Wagner Rodrigues Silva. Este artigo apresenta resultados de investigaçôes produzidas no grupo de pesquisa Práticas de Linguagens - PLES (UFT/CNPq). 
fim, na seçăo Projeto, sim! Pesquisa, sim!, săo apresentadas explanaçôes a respeito de um projeto de pesquisa com tipificaçōes concernente ao gênero.

\section{LETRAMENTO CIENTÍFICO - BUSCA DE UMA INCLUSÃO}

As atividades humanas pessoais e sociais de ensino, de aprendizagem, de trabalho, de convívio e de lazer sâo mediadas por discursos, moldados em gêneros discursivos diversos. A leitura e a escrita organizam as práticas sociais das pessoas em diferentes locais e contextos, essas săo socialmente constituídas na e pela comunidade - podendo ser escolar ou năo escolar. Em qualquer grupo de indivíduos, as práticas sociais se fazem presentes, sâo permeadas pelo ato de ler e escrever, ou seja, pelo letramento, um termo proveniente da concepçấo de que a alfabetizaçáo consistia muito mais do que o ensino do registro e da compreensăo de caracteres linguísticos. Nas últimas décadas, a abordagem do letramento adentrou o ensino de línguas, pelo fato de reconhecer a leitura e a escrita, assim como sua aprendizagem, indissociáveis do agir humano na sociedade.

Para Rios (2010), o letramento é um termo que tem dois sentidos fundamentais: o letramento como um processo na vida social e como um campo de estudos. Como um processo na vida social, porque "o letramento tem início na vida de um indivíduo desde que esteja exposto a textos - sejam em painéis na rua, placas sinalizadoras ou de propaganda [...] - ou a falas que tendem a reproduzir a linguagem de textos" (RIOS, 2010, p. 79), como a leitura de um livro literário para uma criança e o discurso proferido por um padre mediado por preceitos bíblicos. Como campo de estudos porque o letramento se situa numa área interdisciplinar entre Educaçăo, Linguística, Psicologia e as demais Ciências Humanas e Sociais, e, até mesmo, nas denominadas ciências exatas ou naturais como Física, Química, Matemática e Biologia. Nas efetivaçōes de aprendizagem dessas áreas de conhecimento, fazem-se presentes práticas de letramento sociais mediadas por diferentes suportes ou gêneros discursivos, como jornal impresso, livro didático, romance, laudo psicológico, tabela periódica, atlas, tabela, tabuada, dentre outros.

Para cada esfera de atividade humana, faz-se necessário um conjunto de gêneros do discurso para coordenar e organizar melhor as atividades. Alguns gêneros organizam as atividades de pesquisa da esfera científica: entrevista; exposiçâo oral; gráfico; relatório; formulário; projeto de pesquisa; artigo; questionário; dentre outros. Quando se trata da produçấo, compreensâo, leitura e escrita de textos pertencentes a diferentes gêneros do domínio científico, faz-se presente o letramento científico, um tema novíssimo na LA, diferentemente de outras áreas de estudo e pesquisa do Brasil. A título de verificaçăo a respeito do conhecimento científico, o Instituto Abramundo, em parceria com o Instituto Paulo Montenegro e a Ong Açăo Educativa, no ano de 2014, fez um levantamento que objetivou medir e correlacionar o entendimento dos brasileiros em ciências, denominado de Indicador de Letramento Científico (ILC).

As instituiçôes tomaram como ponto de partida o Indicador de Analfabetismo Funcional (INAF) e o Programa Internacional de Avaliaçăo de Estudantes (Pisa)³. Os resul-

3 O Instituto Abramundo foi fundado em 2003 com a missão de disseminar a cultura científica no Brasil. Se destaca por sua competência em aliar ciência, arte, cultura e educação (GOMES, 2015). A Ação Educativa, Assessoria, Pesquisa e Informação, 
tados do ILC foram constituídos pelo intermédio de entrevistas a brasileiros de diferentes regiōes do país, os quais deveriam ter no mínimo quatro anos de escolarizaçăo. Segundo Menezes (2015, p. 27), o levantamento objetivou avaliar "desde o domínio das linguagens, ou seja, a compreensăo de termos de caráter científico-tecnológico, passando pela capacidade pessoal de colocar em prática os conhecimentos científicos" e interpretá-los.

Um total de 2002 cidadăos, residentes em 211 municípios de nove regiōes metropolitanas (Porto Alegre, Rio de Janeiro, Fortaleza, Curitiba, Belo Horizonte, Salvador, Săo Paulo, Recife, Belém, mais o Distrito Federal), foram entrevistados. Esse feito revela a importância de um país possuir cidadāos letrados para o bom desempenho político e econômico da naçấo, entretanto, faz-se necessário ressaltar que o letramento é um termo difícil de ser conceituado e também difícil de ser mensurado. Mas apesar de nâo mensurar fielmente o processo de letramento da populaçăo brasileira, o resultado apontou que é preciso haver mudanças, principalmente na educaçăo em prol da melhoria do letramento científico dos cidadăos.

\section{ALFABETIZAÇÃO CIENTÍFICA E LETRAMENTO CIENTÍFICO - A GUISA DE UMA COMPREENSÃO}

Autores brasileiros da área do Ensino de ciências estăo conclamando uma educaçăo que promova o conhecimento científico nas instituiçōes educacionais, a exemplo de Chassot (2014) e Demo (2010). Ambos afirmam ser necessário aos alunos desde os anos iniciais do ensino fundamental aprender a pesquisar - compreender, interpretar e construir conhecimentos, fenômeno que ambos denominam de Alfabetizaçáo Científica (AC). Conforme os autores, a AC pode potencializar alternativas que privilegiam uma educaçấo mais comprometida com a formaçăo cidadâ. No campo do ensino de ciências, há estudiosos que consideram os termos alfabetizaçāo científica e letramento científico como sinônimos ou com significaçôes semelhantes.

Para Mamede e Zimmermann (2005), os AC e LC referem-se à importância de preparar o indivíduo para a vida em uma sociedade científica e tecnológica, na qual o conhecimento assume um papel essencial, dentro de uma perspectiva crítica da ciência e da tecnologia. As autoras ainda ressaltam que há uma aproximaçâo entre o LC e os objetivos propostos na abordagem da Ciência, Tecnologia e Sociedade (CTS $)^{4}$. Consideram que

a presença da ciência e da tecnologia se coloca no cotidiano e que questóes mais amplas sobre o desenvolvimento científico e tecnológico têm repercussóes diretas sobre a sociedade, o ensino de ciências, dentro desta perspectiva, constitui-se em uma estratégia importante de inclusăo do indivíduo na vida social, de uma maneira

fundada em 1994, é uma associação civil sem fins lucrativos que visa promover direitos educativos, culturais e da juventude, objetivando assegurar a justiça social, a democracia participativa e o desenvolvimento sustentável (AÇÃO EDUCATIVA, 2016). O Instituto Paulo Montenegro é uma organização sem fins lucrativos, criada em 2000 pelas empresas associadas ao Grupo IBOPE, para desenvolver e executar projetos de responsabilidade social, empregando sua expertise e conhecimento acumulado na área de pesquisas em ações que beneficiam a sociedade (UNICEF, 2012).

4 No final da década de 70, começou a surgir em diversos países propostas curriculares com ênfase nas inter-relaçóes Ciência, Tecnologia e Sociedade (CTS). "Tais propostas tinham uma perspectiva marcadamente ambientalista, apresentando uma visáo crítica ao modelo de desenvolvimento; por isso, alguns a identificaram como ciência-tecnologia-sociedade-ambiente (CTSA)" (SANTOS, 2007, p. 477). 
ativa e náo meramente na qualidade de espectador. Ressalta-se a compreensâo da ciência como prática social, o que nos leva a discutir suas condiçôes de produçâo, divulgaçáo e aplicaçâo, bem como a possibilidade de controle sobre a ciência e a tecnologia que a sociedade detém. (MAMEDE; ZIMMERMANN, 2005, p. 02).

O excerto supracitado revela que o conhecimento científico assim como o letramento é socialmente construído e que é necessário incluir o indivíduo em questóes sociais, de forma que eles possam compreender e discutir a aplicabilidade da ciência na sociedade. Em acordo com essas afirmaçóes, Santos (2007, p. 487) enuncia que é preciso desenvolver, na educaçăo científica, "valores estéticos e de sensibilidade, popularizando o conhecimento científico pelo seu uso social como modos elaborados de resolver problemas humanos".

O grande desafio para a alfabetizaçâo científica nas escolas é, segundo Demo (2010, p. 121), construir um currículo de reconstruçáo científica, que conduza os alunos a pesquisar e a produzir textos autorais. Segundo Santos (2007, p. 483), a educaçâo científica na perspectiva do letramento como prática social implica um desenho curricular que incorpore práticas que superem o atual modelo de ensino de ciências predominante nas escolas.

Com respeito à efetivaçăo da leitura e da produçáo textual para o conhecimento científico, a Base Nacional Curricular Comum, homologada em 20 de dezembro de 2017, componente curricular de Língua portuguesa também credita a importância das práticas de linguagem no campo de estudo e pesquisa (BRASIL, 2017), posto que a construçáo e a divulgaçăo do conhecimento científico envolve o uso de múltiplas linguagens em diferentes gêneros do discurso, ou seja, pelo letramento. No âmbito da LA, Tfouni (2010) enfatiza que o letramento é essencial para o discurso científico e a organizaçáo da indústria, do governo e da educaçáo. Na sociedade da informaçáo, nâo basta aos cidadăos e as cidadás serem alfabetizados/das, em um sentido tradicional, devem ser também alfabetizados/das em um tipo especial de cultura letrada, como consideram Segrera e Gumucio (2009).

O letramento é essencialmente um conjunto de práticas socialmente construídas que envolvem a leitura e a escrita (cf. SOARES, 2012). Nesse sentido, a escola precisa compreender o letramento numa dimensăo social mais produtiva, envolvendo muito mais que as tradicionais práticas escolares de leitura e escrita para a escola, no contexto pedagógico. As atividades de iniciaçăo científica devem se configurar em estratégias com usos mais produtivos da tecnologia da escrita. A respeito da educaçăo científica, Demo (2011, p. 37) ressalta que a escola precisa "caprichar na fase formativa da pesquisa", trabalhar o lado da alfabetizaçấo, que, para o autor, tem o sentido propedêutico de iniciaçâo, "introduzir os alunos no mundo do conhecimento científico".

Concernente a uma educaçâo interdisciplinar em funçâo do ensino de linguagem, este artigo traz outras posiçóes sobre a AC e o LC. A de que a primeira seja um fenômeno mais amplo que a apreensăo de conteúdos de física, química e áreas afins. A AC engloba muito mais que o ensino e a aprendizagem de quaisquer áreas da ciência, desde as humanas às naturais, o que se pretende na $\mathrm{AC}$ é a produçăo de conhecimentos mediante questionamentos, investigaçōes, pesquisas e práticas letradas do domínio científico, que denominamos de LC.

Diante disso, cabem aos educadores, independente da área de conhecimento, a promoçấo do LC, dada a sua relevância para o ensino, a aprendizagem e a produçấo do 
conhecimento científico. Os gêneros discursivos necessários para a pesquisa e para a divulgaçáo científica devem ser trabalhados com afinco, de modo que os alunos compreendam, apreendam e façam usos acadêmico e social da linguagem, sobretudo no que concerne à produçấo escrita.

\section{PROJETOS, NÃO! PESQUISAS, SIM OU NÃO?}

As esferas de atividade humana possuem um sistema de gêneros específico para a coordenaçăo das atividades. A iniciaçăo científica nas instituiçôes de ensino, por exemplo, é efetuada por intermédio de vários gêneros textuais, dentre os quais e de suma importância destaca-se o projeto de pesquisa. Um projeto de pesquisa é, notadamente, "um plano de açâo para se sair daqui e chegar lá, onde aqui pode ser definido como o conjunto inicial de questóes a serem respondidas, e lá é um conjunto de conclusóes (respostas) sobre essas questōes" fonte. Entre o aqui e o lá, existe "um grande número de etapas" guiadas por práticas letradas (YIN, 2005, p. 4, grifo do original).

O projeto é importante porque guia as etapas do processo de execuçăo de uma pesquisa. Segundo Marconi e Lakatos (2003, p. 214), em uma pesquisa nada se faz por acaso desde a "escolha do tema, fixaçăo dos objetivos, determinaçăo da metodologia, coleta dos dados, sua análise e interpretaçăo, tudo é previsto no projeto de pesquisa. Este, portanto, deve responder às conhecidas questôes do tipo: O quê? Por quê? Para quê? Para quem? Onde? Como? Com quê? Quanto? Quando? Quem? Com quanto?". Para responder às referidas perguntas, um projeto de pesquisa deve ter em sua estrutura: apresentaçâo (tema, título e informaçôes sobre a entidade pesquisadora e pesquisadores); justificativa; objetivos (geral e específicos); problema a ser pesquisado; hipótese; metodologia, informaçăo do método de abordagem, das técnicas e dos procedimentos de pesquisa; revisâo bibliográfica; cronograma; orçamento e referências bibliográficas. Essa padronizaçấo pode sofrer variaçôes conforme as áreas do conhecimento científico, agências de fomento à pesquisa ou, até mesmo, propósitos do projeto.

Os gêneros acadêmicos ou científicos possuem normatizaçōes, para suas efetivas produçōes, estabelecidas pela Associaçăo Brasileira de Normas Técnicas (ABNT) - órgăo que padroniza as técnicas de produçăo industrial, científica, tecnológica e intelectual. As especificaçóes concernentes à elaboraçáo de um projeto de pesquisa foram estabelecidas pela Norma Brasileira (NBR) - 15287.

A pesquisa de mestrado acadêmico de Fernandes (2016) apontou projetos elaborados por alunos e professores de diferentes escolas palmenses, dissonantes com a normativa proposta pela ABNT. A pesquisa demonstrou poucos projetos das escolas municipais, inscritos na FECIT, considerados como projetos de pesquisa ${ }^{5}$. Alguns até possuem elementos de outros gêneros discursivos, conforme verificável no Exemplo 1.

5 A Secretaria Municipal de Educaçăo de Palmas (SEMED) cedeu à pesquisadora os projetos inscritos na FECIT nos anos 2014 e 2015. 


\section{EXEMPLO 1}

\section{EXERGAMES, COMBATE A OBESIDADE E ALIMENTAÇÃO SAUDÁVEL}

\section{ALUNA A}

ALUNA B

ALUNA C

\section{Junho de 2014.}

1 - OBJETIVOS: Demonstrar o risco para a populaçăo do aumento da obesidade; Apresentar dicas de alimentaçăo saudável; Mostrar novas formas de atividade física;

2 - JUSTIFICATIVAS: Com o grande crescimento da obesidade, se tornando uma epidemia mundial, queremos alertar a populaçăo para este grande problema. Com o projeto da feira do conhecimento temos a possibilidade de informar a comunidade escolar, sobre o risco da obesidade, a importância de uma alimentaçăo saudável de qualidade e novos métodos de praticar uma atividade física mesmo que estando dentro de casa.

\section{3 - METODOLOGIA:}

$1^{\circ}$ Fase - Pesquisar sobre o tema do trabalho (todos).

$2^{\circ}$ Fase - Planejar a exposiçăo da feira (todos).

$3^{\circ}$ Fase - Montar a apresentaçấo (todos).

$4^{\circ}$ Fase - Elaborar os cartazes (todos).

$5^{\circ}$ Fase - Elaborar a apresentaçăo para o Orientador (todos).

$6^{\circ}$ Fase - Montar e organizar o estande (todos).

\section{4 - CONCLUSÕES:}

Com este projeto, conseguimos descobrir uma margem de crescimento e alguns meios de combate a obesidade. Aprendemos dicas de boa alimentaçăo e métodos diferentes de praticar atividades físicas.

Fonte: Projeto cedido pela Secretaria Municipal de Educação (Semed) ${ }^{6}$

6 Os projetos estăo aqui reproduzidos, conforme os originais. Está omitida a identificaçăo dos autores, com 
O projeto do Exemplo 1 foi inscrito na FECIT de 2014. Na capa de apresentaçáo do projeto, săo informados apenas título, nomes dos discentes e data. No projeto, năo há revisáo bibliográfica, hipótese, orçamento e referências bibliográficas. A seçăo identificada como metodologia năo corresponde especificamente aos aspectos metodológicos a serem apresentados em um projeto para o desenvolvimento de uma pesquisa. Trata-se de um cronograma onde há a descriçăo das atividades a serem realizadas nas fases do trabalho desenvolvidas pelos alunos para a participaçấo e elaboraçấo do evento Feira de Ciências ( $1^{\circ}$ Fase - Pesquisar sobre o tema do trabalho (todos). $/ 2^{\circ}$ Fase - Planejar a exposiçáo da feira (todos). $/ 3^{\circ}$ Fase - Montar a apresentaçáo (todos). $/ 4^{\circ} \mathrm{Fase}$ - Elaborar os cartazes (todos). $/ 5^{\circ} \mathrm{Fase}$ - Elaborar a apresentaçáo para - Orientador (todos). $/ 6^{\circ}$ Fase - Montar e organizar o estande (todos)). As práticas pedagógicas que resultam em atividades como a do Exemplo 1 revelam uma iniciaçấo científica simplificada ou, até mesmo, distorcida. 


\section{EXEMPLO 2}

\section{PROJETO FEIRA DE CIÊNCIAS ETI X - 2015}

\section{Prof.Y}

Alunos:

Aluno A - 92.01

Aluno B - 92.01

Aluno C - 92.01

TEMA: Tratamento de esgoto sustentável.

Pré-projeto de ciências

Desenvolver uma maquete mostrando como captar e tratar o esgoto doméstico, sem contaminar o solo e os lençōes freáticos provando o que Antonie Lavoisier já dizia "Na natureza, nada se perde, tudo se transforma". Através da decomposiçâo anaeróbica e um gasômetro e possível transforma o esgoto em fertilizante e gás metano em energia.

O projeto usará a fossa céptica biodigestor, visando-a acabar com as "fossas negras". O nosso grupo desenvolverá um tratamento de esgoto coletivo simplesmente mudando o tamanho e local das fossas rudimentares.

Pretendemos mostrar de uma maneira simples que o ser humano e a natureza podem coexistir juntos no mesmo planeta.

O projeto terá $3^{\circ}$ etapas

$1^{\circ}$ etapa: será usada uma caixa de 1.000 l, ela ficara localizada na residência no qual o liquido coletado será jogado em um tubo que levara a segunda caixa usando o controle de fluxo os dejetos boiaram o que cairá segunda caixa serăo apenas os líquidos gerados na fermentaçăo dos coliformes totais e fecais.

$2^{\circ}$ etapa: terá uma caixa maior de 5.000 l, ficara no final da rua e recebera os líquidos da primeira caixa, como foi explicado acima. Nela também acontecera à decomposiçăo anaeróbica, será colocado também um gasômetro para capta o gás metano gerado nesse processo.

$3^{\circ}$ etapa: será uma caixa de 3000 l, ficará logo após a segunda caixa e receberá apenas líquidos que sobraram de todo esse processo sem nenhum resíduo de coliformes totais e fecais, sabendo que nâo haverá mais nem um agente patogênico nessa terceira caixa, pois eles foram eliminados no processo da segunda caixa. Colocaremos agentes patogênicos na primeira caixa, depois do 
processo de decomposiçâo anaeróbica na terceira caixa năo será encontrado nenhum agente patogênico, nesta mesma caixa será feita um filtro composto por calcário, areia grossa e areia fina, fazendo com que esta agua saia pura (năo potável) com um grande potencial fertilizante.

Nesse processo năo poderá ser usado a agua da pia e do banho porque nela há agentes antibacterianos, e as bactérias săo muito importantes no processo da decomposiçāo.

Será depositado 1 kg de fezes suínas ou bovinas, por mês através dos sanitários de cada casa, pois as bactérias existentes nas fezes bovinas e principalmente suína se alimentam das bactérias que se encontram nas fezes humanas.

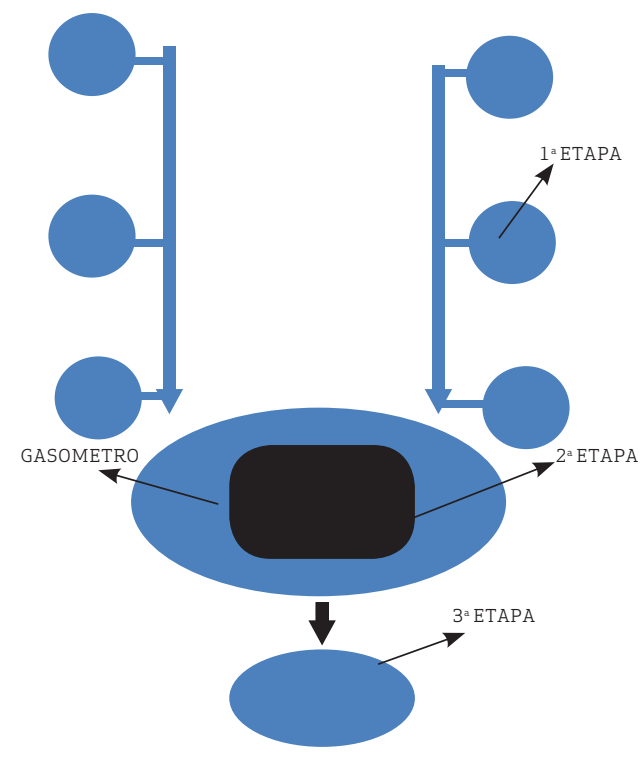

Para o melhor aproveitamento das coisas que podemos usar vamos acrescentar mais uma caixa no qual irar conter lixo orgânico, através da compostagem ele produz um liquido chamado chorume que é rico em gás metano esse liquido pode ser jogado na segunda caixa através de um cano que liga uma a outra.

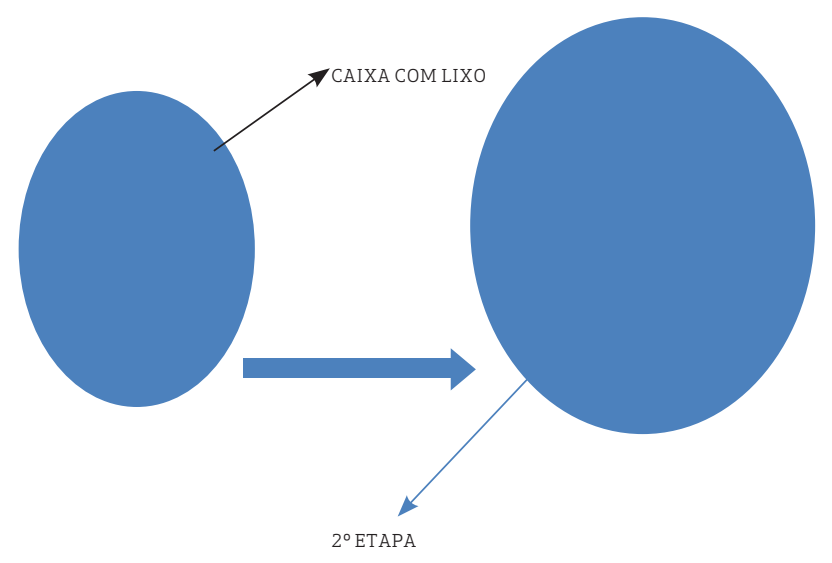


Com isso teremos mais concentraçăo de gás metano e estes serăo usando em geradores de energia que abastecer a todas as casa que desse pré-projeto esta envolvida.

Fonte: Projeto cedido pela Secretaria Municipal de Educação (Semed)

O projeto do Exemplo 2 foi inscrito na FECIT de 2015. Na capa, é informado o nome da instituiçáo, o ano, o nome do professor orientador, o título do trabalho, o nome dos alunos e a série que estavam cursando. Em seguida, por meio de um texto entremeado por duas figuras ilustrativas, é apresentado o que seria realizado pelos alunos (Desenvolver uma maquete mostrando como captar e tratar o esgoto doméstico, sem contaminar o solo e os lençóis freáticos) e as etapas de elaboraçâo de uma fossa séptica biodigestora.

O projeto do Exemplo 1 visou apenas informar sobre a obesidade, seus riscos e formas de prevençáo (Com o projeto da feira do conhecimento temos a possibilidade de informar a comunidade escolar, sobre o risco da obesidade, a importância de uma alimentaçâo saudável de qualidade e novos métodos de praticar uma atividade física mesmo que estando dentro de casa). O projeto do Exemplo 2 objetivou desenvolver uma maquete de uma fossa céptica biodigestora com a pretensâo de mostrar de uma maneira simples que o ser humano e a natureza podem coexistir juntos no mesmo planeta. As etapas mostradas nesse suposto projeto năo foram etapas de uma pesquisa, as quais poderiam ser revisáo bibliográfica, realizaçấo de entrevista, pesquisa de campo, tabulaçăo de dados coletados, realizaçăo de experimentos, dentre outras atividades. Entretanto, foram etapas de como se faz uma fossa que possibilita a decomposiçâo anaeróbica, ou seja, a reproduçâo de um experimento pronto.

Os dois projetos exemplificados nesta seçâo carecem de marcas semióticas necessárias ao gênero projeto de pesquisa. Além disso, as inscriçōes neles descritas revelam que năo săo projetos de pesquisa. Percebemos nos dois textos práticas conteudistas de ensino, atividades corriqueiras das instituiçóes educacionais: informar o já existente, o já pesquisado e sintetizar informaçôes sobre um tema para transmitir a outrem. Um projeto de pesquisa deve ser elaborado para o fim a que se destina, a pesquisa, nele deve estar contido minimamente a justificativa, o problema de pesquisa, as hipóteses, o referencial teórico e as etapas de desenvolvimento da pesquisa.

Os gêneros discursivos possuem finalidades e especificidades diferenciadas. No caso do projeto de pesquisa, guia as etapas de desenvolvimento de uma investigaçâo a ser desenvolvida. Podem ser pesquisa de campo, pesquisa experimental, pesquisa laboratorial ou pesquisa documental. A escolha e efetivaçâo desses tipos de investigaçâo precisam ser guiadas por um projeto.

Por certo, nas atividades realizadas pelos discentes, demonstradas nos Exemplos 1 e 2, năo houve projetos de pesquisa que mediassem as açóes discentes, mas sim, a busca de informaçôes sobre a temática (obesidade) e de instruçôes de como se faz uma fossa séptica biodigestora para representá-la em uma maquete, as quais precisamente foram orientadas pelas figuras presentes no texto exemplificado. Somente após os trabalhos 
serem selecionados para apresentaçăo na FECIT, os alunos escreveram os denominados projetos para se inscreverem no evento. Nesses textos, de modo simplório, os alunos descreveram o desenvolvimento de seus trabalhos. No caso mais específico do Exemplo 2, eles demonstraram por etapas como fazer um experimento de uma fossa. A ausência de um efetivo projeto de pesquisa para guiar os trabalhos discentes evidencia o desconhecimento da funcionalidade do gênero, e sua facçâo após as atividades revelam etapas de um ensino escolarizado.

As práticas pedagógicas de escolarizaçâo, segundo Terra (2013, p. 50), servem para designar um ensino formal e institucional realizado "de maneira contínua, de certo modo linear, cuja meta envolve alcançar um produto final que é passível de ser avaliado/certificado" e "reconhecido oficialmente".

Os dois textos analisados, mediante a tipificaçăo concernente ao gênero, năo podem ser considerados projetos de pesquisa, ambos evidenciaram também que náo houve uma investigaçăo efetivada, de fato, pelas escolas inscritas.

\section{PROJETO, SIM! PESQUISA, SIM!}

Como exemplo de projeto de pesquisa enviado à FECIT, destacamos o projeto Construindo paisagens sustentáveis na quadra 405 norte. Foi elaborado conforme as características concernentes ao gênero projeto de pesquisa: possui capa, resumo do trabalho, introduçāo, justificativa e motivaçăo (com citaçóes sobre a temática), objetivos, materiais e métodos, resultados, bibliografia e anexos. Entre os projetos inscritos, alguns se encontravam em fase de execuçăo e outros já finalizados, como é o caso do projeto mencionado, conforme verificável no resumo do projeto, reproduzido no Exemplo 3. 


\section{EXEMPLO 3}

\section{RESUMO:}

A pesquisa foi realizada na quadra 405 Norte onde há uma grande quantidade de lixo espalhados em seus logradouros formando paisagens urbanas insustentáveis. Constatou-se que os moradores têm interesse de mudar essas paisagens, mas falta açăo do poder público para promover uma política eficiente de resíduos sólidos na regiăo, colocando em prática o Plano Nacional de Resíduos Sólidos. Existem iniciativas como a Associaçâo dos catadores de recicláveis da regiăo Norte (ASCAMPA) que pode ser potencializado o seu o trabalho e com isso diminuir-se-ia o problema do resíduo sólido descartado inadequadamente pela populaçáo.

O projeto foi executado por alunos do $9^{\circ}$ ano da EJA, alunos que ainda possuíam muita dificuldade com a escrita. De acordo com o professor orientador do projeto, os alunos tiveram aulas sobre paisagens geográficas quando estavam no $7^{\circ}$ ano. Eles foram bastante receptivos às referidas aulas. Quando os professores informaram sobre a feira de ciências, alguns alunos manifestaram o desejo de pesquisar as paisagens da quadra onde a escola se situa. O projeto consistiu em caminhadas pela quadra para registro de fotos das paisagens insustentáveis ${ }^{7}$ e visitas aos moradores para aplicaçăo de questionários sobre paisagem, sustentabilidade e reciclagem, com o intuito de atingir os seguintes objetivos: Promover a destinaçāo adequada dos resíduos sólidos encontrados nos logradouros públicos da quadra 405 norte; Implementar a cultura da reciclagem e da coleta seletiva entre os moradores; Aproximar moradores da quadra com a Associaçâo dos Catadores de Lixo da Regiâo Norte de Palmas (ASCAMPA); e Promover a saúde preventiva dos habitantes da quadra.

Os dados descritos no projeto evidenciam uma pesquisa realizada. A metodologia foi executada e os objetivos alcançados. Nos anexos do projeto, a exemplo, estâo organizadas fotos de resíduos sólidos existentes nos terrenos baldios da quadra, fotos de uma associada da ASCAMPA no seu ofício, questionário que foi aplicado a moradores da quadra. Os resultados do questionário foram tabulados e convertidos em gráficos dispostos no corpo do projeto como se pode verificar no Exemplo 4.

7 Paisagens insustentáveis săo cenas que degradam o meio ambiente, rios poluídos, terrenos baldios preenchidos com descartes de materiais, muitos reutilizáveis e recicláveis, como móveis e entulhos de construçăo civil. 


\section{EXEMPLO 4}

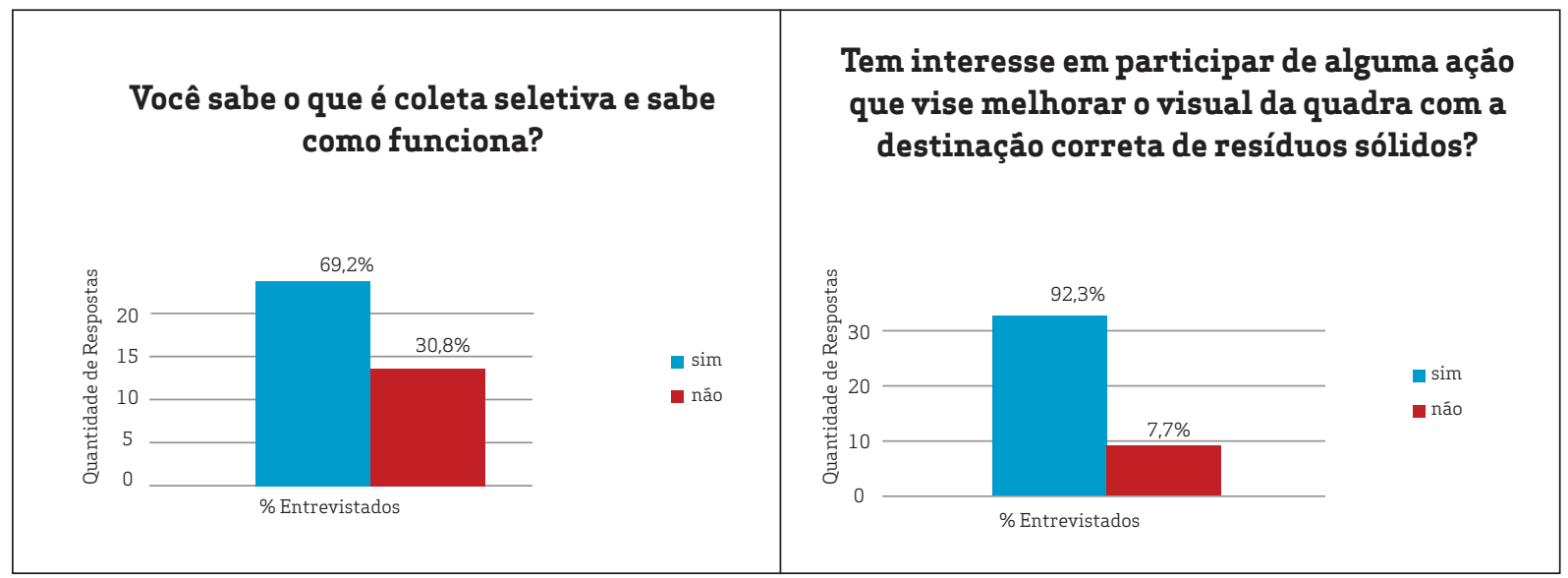

Fonte: Projeto cedido pela Secretaria Municipal de Educação (Semed)

O projeto demonstrou uma pesquisa com as etapas comuns à atividade de investigaçâo científica. O desenvolvimento contou com a participaçấo de vários atores sociais: escola; associaçấo; alunos; professor; moradores da quadra; e associados da ASCAMPA, associaçăo de reciclagem que se situa ao lado da escola. Muitos moradores do local e quadras vizinhas desconheciam a associaçăo, bem como os processos de reciclagem. A pesquisa proporcionou o conhecimento, conscientizaçăo e aproximaçăo dos moradores da Quadra 405 Norte e de quadras vizinhas à ASCAMPA, como se pode verificar no excerto de entrevista com o professor da escola campo, reproduzido no Exemplo 5. Trata-se da fala do professor orientador da pesquisa.

\section{EXEMPLO 5}

Năo foi um trabalho assim, digamos, nâo foi um trabalho aprofundado. Mas eles, através de fichas, fizeram uma pesquisa na quadra a respeito do problema dessas paisagens, que nós chamamos de sustentáveis ou insustentáveis devido à degradaçăo do meio ambiente e até visual desses descartes. Eles entrevistaram moradores com a orientaçăo nossa. Tiveram contato com o pessoal de uma cooperativa, da ASCAMPA. Entăo foi muito positivo para eles verem como é o trabalho, o mecanismo. Os discentes fotografaram, entrevistaram o pessoal, as lideranças e os convidaram para a Feira. Eles vieram no dia da apresentaçăo e falaram do trabalho deles, sensibilizaram as pessoas que estavam aqui, muitos até pegaram o contato para ao invés de jogar na rua alguma coisa, ligar na ASCAMPA. O pessoal da própria ASCAMPA agradeceu muito, a presidente falou com a comunidade que estava aqui, distribuíram folders. Entăo virou uma espécie de palestra, apesar da feira ser coletiva (disse sorrindo). Foi isso o que ocorreu sabe. Foi um trabalho simples, a gente ajudou, logicamente. Vemos que o problema da EJA, a escrita, é muito complicado, auxiliamos muito eles nesse aspecto (Relato do Professor Orientador).

No Exemplo 5, o excerto da entrevista revela o quanto a pesquisa foi importante 
para os atores sociais envolvidos, o professor relata que foi muito bom os alunos conhecerem a ASCAMPA, o processo de reciclagem; bem como alguns representantes da referida associaçăo terem participado da feira de ciências da escola para divulgarem o trabalho da cooperativa. O Exemplo 5 também denota a interaçăo entre os atores pelo intermédio da linguagem.

Por intermédio da entrevista, um gênero de muita importância para coleta de dados e informaçóes em uma pesquisa, o professor enunciou ainda outros gêneros mediados pela escrita (apresentaçâo, folder, palestra), os quais, juntamente com a entrevista, mediaram a comunicaçăo dos discentes com os moradores, com o presidente e com os associados da ASCAMPA e do presidente da ASCAMPA com a comunidade presente na feira de ciências da escola.

O projeto visou à promoçăo de açóes práticas, individuais e coletivas, para além da conscientizaçăo, envolveu mudanças de atitudes, comportamentais. A efetivaçâo do projeto proporcionou o "pensar agir" e, até mesmo, o "agir" de moradores de quadras vizinhas à escola em prol da melhoria ambiental, sustentável e paisagística. Na visâo do Grupo da Nova Londres, a mente, a sociedade e a aprendizagem săo baseadas na suposiçâo de que a mente humana é incorporada", situada e social e "a construçáo do conhecimento humano năo se efetiva de modo geral e abstrato, mas como inseridos em contextos sociais, culturais e materiais" (THE NEW LONDON GROUP, 2006, p. 20, grifo do original).

Na entrevista, o professor também menciona a importância da funcionalidade da escrita na constituiçăo de atividades científicas (Foi isso o que ocorreu sabe, foi um trabalho simples, a gente ajudou logicamente. Vemos que o problema da EJA, a escrita, é muito complicado, auxiliamos muito eles nesse aspecto). Sobre a relevância da escrita na pesquisa para introduzir os alunos no mundo do conhecimento, Demo (2011) enfatiza que é necessário permitir que os alunos pesquisem e escrevam com autonomia e autoria. Para esse fim, os discentes precisam realizar pesquisas inéditas e produzir novos conhecimentos sobre um assunto e náo relatar pesquisas já realizadas ou propagar conhecimentos já prontos, conforme verificamos nos projetos analisados na seçăo anterior.

O último projeto exemplificado, apesar de evidenciar uma pesquisa simples, sem necessidade de laboratórios sofisticados, atesta que os alunos puderam desenvolver o projeto de pesquisa e alcançar os objetivos propostos - demonstrar a presença de paisagens insustentáveis, conscientizar os moradores a respeito da problemática e apresentar alternativas de mudanças. Quanto à escrita autoral, característica específica para a elaboraçăo de gêneros constitutivos do domínio científico, os professores precisam compreender as tipificaçôes dos gêneros para que seus alunos possam apreendê-los e produzi-los, sendo necessário o auxílio dos docentes na produçăo, sobretudo na fase escolar da rede municipal - o ensino fundamental.

8 Incorporada no sentido de que a mente humana náo é dissociada da realidade material e social. Pelo contrário, é construída por fatores sociológicos, ideológicos, contextuais, materiais, bem como, imateriais. E ela que molda e impulsiona as açóes humanas. 


\section{CONSIDERAÇÕES FINAIS}

As análises demonstraram que a produçăo dos gêneros discursivos do domínio científico depende de uma efetiva pesquisa em desenvolvimento. Os supostos projetos elaborados mediante situaçôes ditas como de pesquisa, as quais năo se configuram como investigaçôes, nâo atenderam aos requisitos constitutivos do gênero discursivo - projeto de pesquisa. Esse feito reflete a prática de um ensino tradicional e conteudis$\mathrm{ta}$, que prevalece nos ambientes institucionais, por motivos diversos, dentre os quais: (i) currículo de ensino-aprendizagem defasados, tanto o do ensino básico quanto 0 do ensino superior; (ii) falta de formaçăo continuada - sobretudo no que concerne à educaçấo pela pesquisa, pelos questionamentos e pelo aprimoramento da criticidade. Essas lacunas sâo algumas das causas de uma educaçăo científica năo proficiente.

O projeto Construindo paisagens sustentáveis na quadra 405 norte revelou práticas de uma pesquisa autoral. Evidenciou a presença da AC e da LC, pelo direcionamento das atividades de pesquisa e produçấo textual por parte do professor orientador. Apesar de uma presença incipiente da AC e da LC nas instituiçóes educacionais, a educaçăo científica nos ambientes educacionais pode se efetivar com mais veemência com a reestruturaçâo do currículo das licenciaturas e do currículo da educaçâo básica; bem como com o investimento na formaçấo profissional do professor como pesquisador e produtor de conhecimentos. 


\section{REFERÊNCIAS}

AÇĀO EDUCATIVA: Quem Somos. Disponível em: <http://www.acaoeducativa.org.br/ index.php/quem-somos>. Acesso em: 10 jun. 2016.

ANGROSINO, Michael. Etnografia e observaçáo participante. Traduçăo José Fonseca. Porto Alegre: Artmed, 2009.

ASSOCIAÇĀO BRASILEIRA DE NORMAS TÉCNICAS - ABNT.NBR15287-Informaçâo e documentaçăo - Projeto de pesquisa - Apresentaçăo. Rio de Janeiro, 2011.

BAKHTIN, Mikhail. Os gêneros do discurso. In: BAKHTIN, M. Estética da criaçâo verbal. Săo Paulo: Martins Fontes, 2003, p. 261-306.

BRASIL. Ministério da Educaçăo. Base Nacional Curricular Comum. Disponível em: http://basenacionalcomum.mec.gov.br//. Acesso em: 16 fev. 2017.

CELANI, Maria Antonieta Alba. A Relevância da Linguística Aplicada na Formaçăo de uma Política Educacional Brasileira'. In: FORTKAMP, M.B.M. \& TOMITCH, L.M.B. (Orgs.) Aspectos da linguística Aplicada. Florianópolis: Insular, 2008, p. 17-32.

CHASSOT, Attico. Alfabetizaçâo científica: questóes e desafios para a educaçáo. 6. ed. Ijuí: Editora Unijuí, 2014.

DEMO, Pedro. Educaçăo e alfabetizaçăo científica. Campinas: Papirus, 2010, 160p.

DEMO, Pedro. Praticar ciência: metodologias do conhecimento científico. Săo Paulo: Saraiva, 2011, 208p.

FERNANDES, Elizangela da Rocha. Letramento científico no ensino básico público no município de Palmas - Tocantins. 2016. 106f. Dissertaçăo (Mestrado em Letras: Ensino de Língua e Literatura) - Universidade Federal do Tocantins, Araguaína, 2016.

FEBRACE. 0 que é a Febrace. Disponível em: http://febrace.org.br/o-que-e-a-febrace/\#. V5F2nbgrLIV. Acesso em: 24 de maio de 2016.

GOMES, Anderson S. L. (Org.). Letramento Científico: um indicador para o Brasil. Săo Paulo: Instituto Abramundo, 2015.

LAKATOS, Eva Maria; MARCONI, Marina de Andrade. Fundamentos de metodologia científica. 5. ed. Săo Paulo: Atlas, 2003.

MAMEDE, Maíra; ZIMMERMANN, Erika. Letramento científico e CTS na formaçăo de professores para o ensino de física. In: SIMPÓSIO NACIONAL DE ENSINO DE FÍSICA, 16. 2005, Rio de Janeiro. Anais... Sáo Paulo: Sociedade Brasileira de Física, 2005. Disponível em:<http://www.sbf1.sbfisica.org.br/eventos/snef/xvi/cd/listatrabcompleta.html>. Acesso em: 10 dez. 2015.

MENEZES, Luís Carlos. Prefácio. In: GOMES, Anderson, S. L (Org). Letramento Científico: um indicador para o Brasil. Săo Paulo: Instituto Abramundo, 2015. 
MOITA LOPES, Luiz Paulo. A transdisciplinaridade é possível na Linguística Aplicada no Brasil. In: SIGNORINI, Inês; CAVALCANTI, Marilda (Orgs). Linguística Aplicada e Transdisciplinaridade: questōes e perspectivas. Campinas: Mercado das Letras, 1998, p. 113-128.

OLIVEIRA, Maria Marly. Como fazer pesquisa qualitativa. Petrópolis: Vozes, 2007.

PALMAS. Diário Oficial da Uniăo - PORTARIA/GAB/SEMED/N. 0361. (2014). Disponível em:<http://www.jusbrasil.com.br/diarios/84404110/dom-pmw-normal-31-03-2014pg-12>. Acessado em: 18 mar 2015.

RIOS, Guilherme Veiga. Consideraçôes sobre letramento, escolarizaçăo e avaliaçăo. In: RESENDE, Viviane de Melo.; PEREIRA, Fábio Henrique. Práticas Socioculturais e Discurso: Debates transdisciplinares. Covilhă: LabCom Books, 2010.p.77-107.

SANTOS, Wildson Luiz Pereira. Educaçăo científica na perspectiva de letramento como prática social: funçōes, princípios e desafios. Revista Brasileira de Educaçáo, Rio de Janeiro, v. 12, n. 36, p. 474-550, 2007.

SEGRERA, Francisco López; GUMUCIO, Cristian Parker. Alfabetismo científico, misión de launiversidad y cidadania: ideas para suconstrucciónem los países envías de desarrollo. Avaliaçâo, Campinas; v. 14, n. 2, p. 267-290, 2009.

SOARES, Magda. Letramento: um tema em três gêneros. Belo Horizonte: Autêntica Editora, 2012.

TERRA, Márcia Regina. Letramento \& letramentos: uma perspectiva sócio-cultural dos usos da escrita. Documentaçáo de Estudos em Linguística Teórica e Aplicada - DELTA. Sáo Paulo: PUCSP, v. 29, n. 1, p. 29-58, 2013.

TFOUNI, Leda Verdiani. Letramento e Alfabetizaçâo. 9a ed. Săo Paulo: Cortez, 2010.

THE NEW LONDON GROUP. A pedagogy of Multiliteracies designing social futures. In: Cope, B; Kalantzis, M. Multiliteracies: literacy Learning and the design of social futures. London e New York: Routledge, 2000, p. 9-37.

UNICEF. Plataforma dos Centros Urbanos: Síntese dos resultados das consultas participativas do Rio de Janeiro. Maio, 2012. Disponível em: < http://www.unicef.org/brazil/pt/ relatorio_consultas_final_RJ.pdf >. Acesso em: 10 jun. 2016.

YIN, Robert K. Estudo de caso: planejamento e métodos. 3. ed. Porto Alegre: Bookman, 2005, 207p.

Recebido em novembro de 2017.

Aceite em março de 2018. 